\title{
Liquid organomineral fertilizer containing humic substances on soybean grown under water stress
}

\author{
Marcelo R. V. Prado ${ }^{1}$, Oscarlina L. dos S. Weber², Milton F. Moraes ${ }^{3}$, \\ Carlos L. R. dos Santos ${ }^{4} \&$ Morgana S. Tunes ${ }^{5}$ \\ ${ }^{1}$ Universidade Federal de Mato Grosso/Programa de Pós-Graduação em Agricultura Tropical. Cuiabá, MT. E-mail: vilelamarcelo@yahoo.com.br \\ (Corresponding author) \\ ${ }^{2}$ Universidade Federal de Mato Grosso/Departamento de Fertilidade Química de Solo. Cuiabá, MT. E-mail: oscsanwb@cpd.ufmt.br \\ ${ }^{3}$ Universidade Federal de Mato Grosso/Departamento de Nutrição Mineral de Plantas. Barra do Garças, MT. E-mail: moraesmf@yahoo.com.br \\ ${ }^{4}$ Universidade Federal de Mato Grosso/Departamento de Nutrição Mineral de Plantas. Cuiabá, MT. E-mail: calersantos@gmail.com \\ ${ }^{5}$ Escola Técnica Estadual/Secretaria de Estado, Ciência, Tecnologia e Inovação de Mato Grosso. Poxoréu, MT. E-mail: tunesmorgana.santos@hotmail.com
}

\section{Key words:}

humic and fulvic acids

biostimulants

plant mineral nutrition

\begin{abstract}
A B S T R A C T
This study evaluated the effect of an organomineral fertilizer enriched with humic substances on soybean grown under water stress. The experiment was performed in a greenhouse using a Red Latosol (Oxisol) with adequate fertility as substrate, in which soybean plants were cultivated with and without water stress. The experimental design was randomized blocks, in a $2 \times 5$ factorial scheme (two moisture levels and five fertilizer doses: $0,1,2,4$ and $8 \mathrm{~mL} \mathrm{dm}^{-3}$ ), totaling 10 treatments, with four replicates. The organomineral fertilizer was applied in the soil 21 days after plant emergence and the water regimes were established one week thereafter. The fertilizer was not able to attenuate the effects of water stress, reducing soybean grain yield by more than $50 \%$ compared with plants cultivated under no stress. Fertilizer doses caused positive response on soybean nutrition and grain yield and, under water stress condition, the most efficient dose was $5.4 \mathrm{~mL} \mathrm{dm}^{-3}$. There were lower leaf concentrations of nitrogen, phosphorus and potassium and higher concentrations of sulfur in plants under stress. Humic substances favor the absorption of micronutrients.
\end{abstract}

\section{Palavras-chave:}

ácidos húmicos e fúlvicos bioestimulantes nutrição mineral de plantas

\section{Fertilizante organomineral líquido contendo substâncias húmicas em soja cultivada sob estresse hídrico}

\begin{abstract}
R E S U M O
Avaliou-se, neste trabalho, o efeito de um fertilizante organomineral enriquecido com substâncias húmicas em soja submetida a estresse hídrico. Em casa de vegetação foi realizado um experimento utilizando-se, como substrato, um Latossolo Vermelho com nível de fertilidade adequado no qual foram cultivadas plantas de soja em duas condições, sem e com estresse hídrico. O delineamento foi em blocos casualizados em esquema fatorial 2 x 5 (dois níveis de umidade e cinco doses: $0,1,2,4$ e $8 \mathrm{~mL} \mathrm{dm}^{-3}$ ) totalizando 10 tratamentos, com 4 repetições. O fertilizante organomineral foi aplicado ao solo 21 dias após a emergência das plantas estabelecendo-se, uma semana após sua aplicação, os níveis de umidade. $O$ fertilizante organomineral não foi capaz de atenuar os efeitos adversos do estresse hídrico reduzindo a produtividade dos grãos de soja em mais de $50 \%$ quando comparado às plantas cultivadas sem estresse hídrico. Houve resposta positiva quanto às doses sobre a nutrição e produtividade de grãos sendo que, na condição de estresse hídrico, a mais eficiente foi $5,4 \mathrm{~mL} \mathrm{dm}^{-3}$; foi menor a concentração foliar de nitrogênio, fósforo e potássio nas plantas com estresse e maior concentração de enxofre; as substâncias húmicas favorecem a absorção de micronutrientes.
\end{abstract}




\section{INTRODUCTION}

The increase in the contents of soil organic matter (SOM) improved physical, chemical and biological attributes and stimulated plant growth and development (Zandonadi \& Busato, 2012; Baldoto et al., 2012; Canellas \& Olivares, 2014; Zandonadi et al., 2014).

Humic substances (HSs) are one of the main components of SOM. Besides the positive effects on soil attributes, they have direct effect on plant physiology and growth, especially for stimulating root growth (Rima et al., 2011; Canellas \& Olivares, 2014). Many studies show that HSs increase the absorption of nutrients due to the increment in the permeability of the cell membrane; chelation and the carrying of nutrients have an auxin-like hormone effect and reduce the effects of the damages caused by the abiotic stress (García et al., 2012). However, various HS-based products have appeared in the market in the last years, which are usually extracted from peat or leonardite, enriched or not with nutrients and registered at the Ministry of Agriculture, Livestock and Food Supply (MAPA) as organic fertilizers, organomineral fertilizers or soil conditioners, although they are commercialized as plant biostimulants (Benites et al., 2006; Zandonadi \& Busato, 2012).

Although many studies have shown the favorable effects of using these products, such as Nikbakht et al. (2008), who applied in nutrient solution doses from 0 to $1000 \mathrm{mg} \mathrm{L}^{-1}$ of humic substances in Gerbera jamesonii plants, and Duplessis \& Mackenzie (1983), who applied leonardite in area cultivated with corn, other studies report that the agricultural use of commercial HSs have no positive effects on plant development, since the applications depend on the origin of the material, method of extraction, concentration and composition of the humic extract. Additionally, the development stage and the environment of the cultivated species interfere with the effect of HSs, although the best results occur when they are used in soils with low contents of organic matter or when the plant is cultivated under stress conditions, whether nutritional or climatic (Hartz \& Bottoms, 2010).

Considering that HSs can favor the cultivation of plants, the soybean crop will also benefit from their application; however, it is notable the need for studies aiming to establish an ideal dose of the organomineral fertilizer.

Thus, this study aimed to evaluate the effect of the application of doses of organomineral fertilizer enriched with HSs on the growth, development, mineral nutrition and yield of soybean cultivated under water stress conditions.

\section{Material AND Methods}

The experiment was carried out in a greenhouse, in the municipality of Poxoréu - MT, at the Technical School of Poxoréu, unit of the State Secretariat of Science, Technology and Innovation (SECITEC), at the geographic coordinates of $15^{\circ} 48^{\prime} \mathrm{S}$ and $54^{\circ} 27^{\prime} \mathrm{W}$.

The organomineral fertilizer was enriched with humic substances extracted from peat through chemical fractionation using $0.5 \mathrm{~mol} \mathrm{~L}^{-1} \mathrm{KOH}$ and acidification with $2 \mathrm{~mol} \mathrm{~L}^{-1} \mathrm{H}_{2} \mathrm{PO}_{4}$, without subsequent purification. For the determination of macro and micronutrients, the organomineral fertilizer was chemically characterized according to EMBRAPA (1997). The fractions humic acids and fulvic acids were separated through the method described in Swift (1996) and the total organic carbon was quantified through the modified method of Walkley-Black, described in Tedesco et al. (1995). The results of chemical and physical characterization of the organomineral fertilizer were: density $=1.1 \mathrm{~g} \mathrm{~mL}^{-1} ; \mathrm{pH}$ in $\mathrm{CaCl}_{2}=9.0 ; \mathrm{N}=1.1 \mathrm{~g} \mathrm{~L}^{-1} ; \mathrm{K}=17.0 \mathrm{~g} \mathrm{~L}^{-1} ; \mathrm{B}=14.8 \mathrm{~g} \mathrm{~L}^{-1} ; \mathrm{Zn}=$ $35.0 \mathrm{~g} \mathrm{~L}^{-1} ; \mathrm{CEC}=850 \mathrm{cmolc} \mathrm{dm}^{-3}$; Organic $\mathrm{C}=35.0 \mathrm{~g} \mathrm{~L}^{-1}$; Total humic extract $=108.0 \mathrm{~g} \mathrm{~L}^{-1}$; Humic acid $=58 \mathrm{~g} \mathrm{~L}^{-1}$ and Fulvic acid $=50.0 \mathrm{~g} \mathrm{~L}^{-1}$.

The experiment was set in a randomized block design, in $2 \times 5$ factorial scheme, which corresponded to two levels of soil moisture (90 and 30\% of water holding capacity SWHC) and five doses of organomineral fertilizer enriched with humic substances $\left(0,1,2,4\right.$ and $8 \mathrm{~mL}$ per $\mathrm{dm}^{-3}$ of soil), with four replicates. These doses were determined according to the recommendation of Matias (2010), mixed with water to obtain a final volume of $100 \mathrm{~mL}$ and applied to the pots 21 days after emergence (DAE). The control of moisture levels started at 28 DAE.

Plots consisted of two $10-\mathrm{dm}^{3}$ pots, each of which cultivated with two soybean plants, cultivar 'TMG 132RR'. Half of the pots were harvested when soybean plants were at flowering for the evaluation of nutritional status and biomass, while the other pots were harvested at the end of the crop cycle for the determination of grain yield and biomass, in a total of 40 experimental units.

The soil used for filling the pots was collected in the layer of 0-0.2 m of a cultivated area and was classified as eutrophic Red Latosol with medium texture (EMBRAPA, 2006). Its physical and chemical characteristics are described in Table 1.

Soil water holding capacity (SWHC) and permanent wilting point (PWP) were determined through the gravimetric and physiological methods, respectively. The soil moisture levels adopted in the pots were 90 and $30 \%$ of SWHC, according to the recommendation of Vasconcelos et al. (2009). Soil moisture levels were determined using electrical impedance sensors installed in ten pots and the moisture was controlled through manual waterings.

Before sowing, the seeds of the soybean cultivar 'TMG 132 RR' (medium cycle) were treated with a fipronil-based insecticide, fertilized with micronutrients (cobalt and molybdenum) and inoculated with Bradirhizobium japonicum, at the doses indicated by the manufacturer. On October 1,2012,

Table 1. Physical and chemical characteristics of the soil used in the cultivation of soybean under greenhouse conditions

\begin{tabular}{|c|c|c|c|c|c|c|c|c|c|c|c|c|c|c|c|c|c|}
\hline & $\mathrm{H}+\mathrm{Al}$ & Al & $\mathrm{Ca}$ & Mg & K & $\mathbf{P}$ & $\mathrm{Zn}$ & $\mathrm{Cu}$ & $\mathrm{Fe}$ & $\mathbf{M n}$ & B & \multirow{2}{*}{$\begin{array}{c}\text { CEC } \\
\mathrm{cmol}_{\mathrm{C}} \mathrm{dm}^{-3}\end{array}$} & \multirow{2}{*}{$\begin{array}{l}\mathbf{V} \\
\%\end{array}$} & OM & Sand & Silt & Clay \\
\hline pr & \multicolumn{4}{|c|}{$\mathrm{cmol}_{\mathrm{c}} \mathrm{dm}^{-3}$} & \multicolumn{7}{|c|}{$\mathrm{mg} \mathrm{dm^{-3 }}$} & & & \multicolumn{4}{|c|}{$\mathrm{g} \mathrm{kg}^{-1}$} \\
\hline 5.5 & 3.1 & 0.0 & 4.1 & 0.9 & 93.8 & 18.3 & 4.6 & 1.4 & 142 & 18.6 & 0.5 & 8 & 62 & 20 & 650 & 45 & 305 \\
\hline
\end{tabular}

$\mathrm{pH}$ - Potential of hydrogen in $\mathrm{CaCl}_{2}\left(1: 2.5\right.$ ratio); $\mathrm{OM}$ - Organic matter extracted using potassium dichromate; $\mathrm{Ca}, \mathrm{Mg}$ and $\mathrm{Al}$ (extracted with 1.0 mol $\left.\mathrm{L}^{-1} \mathrm{KCl}\right) ; \mathrm{H}^{-} \mathrm{Al}\left(0.01 \mathrm{~mol} \mathrm{~L}^{-1} \mathrm{calcium}\right.$ acetate); K, P, Cu, Fe and Mn (Mehlich-1); B (hot water); CEC - Cation exchange capacity (pH 7); V - Base saturation 
five seeds were manually sown in each pot, which received basal fertilization with $330 \mathrm{~kg} \mathrm{ha}^{-1}$ of single superphosphate (SSP). At 16 DAE, thinning was performed, leaving only two plants per pot and top-dressing fertilization was applied using the equivalent to $75 \mathrm{~kg} \mathrm{ha}^{-1}$ of granulated potassium chloride $(\mathrm{KCl})$, based on the recommendation of Sousa \& Lobato (2004). For both basal and top-dressing fertilizations, the doses of SSP and $\mathrm{KCl}$ were determined as a function of the surface of the pots. SSP was applied to the side and below the seeds, while $\mathrm{KCl}$ was distributed on the surface of the pot.

During the experiment, spontaneous plants were manually weeded and the management with insecticides and fungicides was carefully performed not to use products containing micronutrients or biostimulatory substances.

The experiment was evaluated at two stages: 1) at flowering: height, from the soil to the insertion of the last trifoliate leaf, shoot and root dry matter and contents of macro and micronutrients in the diagnostic leaf; and 2) at harvest, performed at the physiological maturation: shoot and root dry matter and grain yield. For biomass determination, plants were cut at the base and the roots were separated from the substrate through washing with running water. Shoots and roots were dried in a forced-air oven and then weighed for the determination of shoot dry matter (SDM) and root dry matter (RDM).

For the determination of the contents of macro and micronutrients, the second, third and fourth trifoliate leaves were collected, including the petiole, using the analytical methods described in Malavolta et al. (1997). At physiological maturation, the pods were collected and the grains were separated for the determination of yield; only after that the moisture of the harvested grains was corrected to $13 \%$.

The obtained data were subjected to Shapiro-Wilk test to verify normality and analysis of variance by $\mathrm{F}$ test; the differences between doses in both treatments of soil moisture were determined using the program Sigma Plot Version 10.0, through polynomial regression.

\section{Results AND Discussion}

Biometric parameters were severely affected in the treatments with soil moisture level of 30\% SWHC, indicating water stress conditions. Under this condition, plants grew $15 \%$ less than those cultivated at 90\% SWHC (Figure 1A). The lower water availability also affected the accumulation of biomass (Figures $1 \mathrm{~B}$ to $1 \mathrm{E}$ ); there were reductions of $30 \%$ in RDM and 50\% in SDM in plants evaluated at flowering and at harvest. These results are expected, because plant physiological processes are dependent on water (Gil \& Tuteja, 2010).

At each soil moisture level, there were increments and all of them followed a quadratic model as a function of organomineral fertilizer doses (Figures 1A to 1E). However, the contributions from the fertilizer were more evident in plants cultivated under water stress conditions. This was also observed by Vasconcelos et al. (2009), who evaluated plants of soybean and corn subjected to the application of HS-rich products.

These more evident effects may have occurred due to the water stress condition to which soybean plants were subjected;

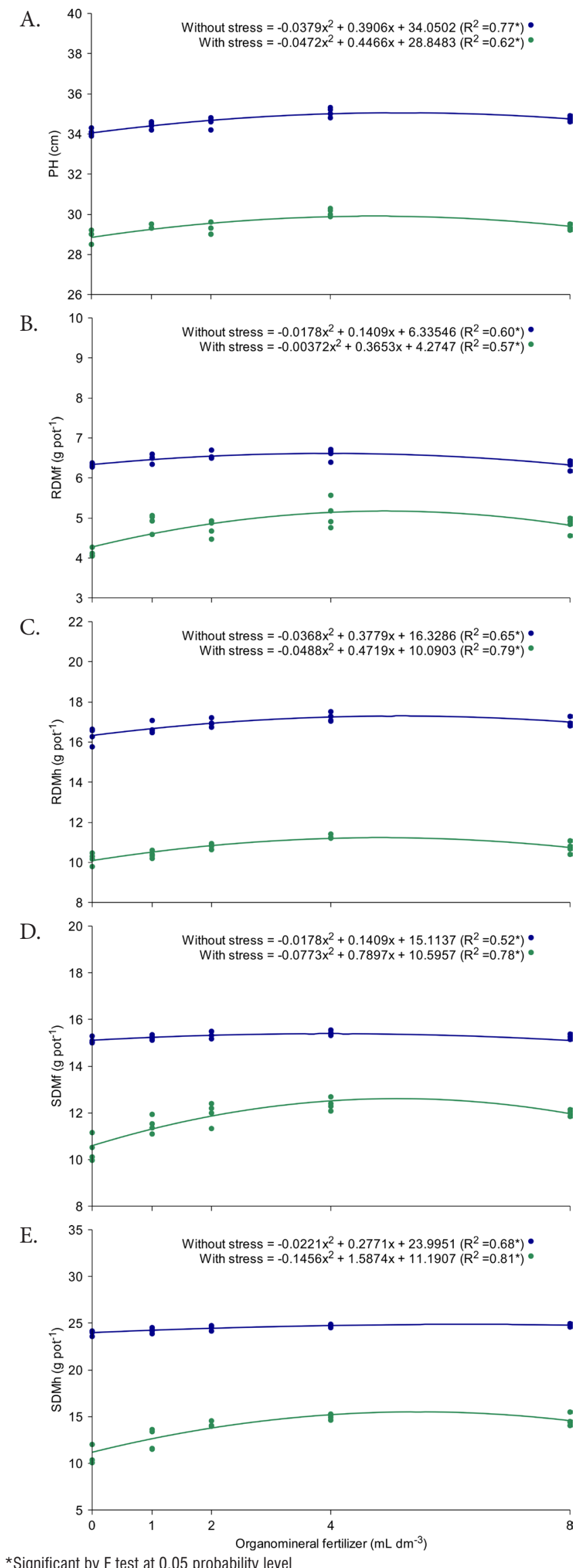

* Significant by $\mathrm{F}$ test at 0.05 probability level

Figure 1. Biometric parameters as a function of doses of organomineral fertilizer with and without stress: plant height - $\mathrm{PH}(\mathrm{A})$; root dry matter at flowering - RDMf (B); root dry matter at harvest - RDMh (C); shoot dry matter at flowering - SDMf (D) and shoot dry matter at harvest - SDMh (E) 
however, the responses were not better probably because the water stress was very severe. Results obtained by García et al. (2012), who applied HS doses in rice plants under water stress, showed that under this condition there was stimulation to the production of the enzyme superoxide dismutase, which, depending on intensity, combats free radicals that damage cell membranes, mitigating the adverse effects of water stress.

Under this condition (with water stress) and compared with the control (without the application of organomineral fertilizer) at the highest accumulations of biomass observed in the stages of flowering and physiological maturation (harvest), there were increments from 13 to $16 \%$ in RDM, and from 18 to $32 \%$ in SDM. Eyheraguibel et al. (2008) also applied HSs via soil, in corn plants, and observed increase in shoot and root biomass. These authors attributed the benefits to the increment of up to $25 \%$ in water use efficiency by the plants that received HSs.

In general, the doses that promoted the best results for biometric parameters varied from 5 to $6 \mathrm{~mL} \mathrm{dm}^{-3}$ of soil, which is equivalent to 175 to $210 \mathrm{mg}$ of $\mathrm{C} \mathrm{dm}^{-3}$ of soil.

The highest increment of biomass observed may have been due to the effect of HSs, which act as hormones, stimulating root growth and the absorption of nutrients by plants. According to Canellas \& Façanha (2004), such stimulation is related to the increase in the permeability of the plasmatic membrane and the activation of $\mathrm{H}^{+}$-ATPase, generating energy and electrochemical gradient, which are essential for plant growth and development. It also promotes root growth, which improves the absorption of water and nutrients. In the corn crop, HSs are able to modify the morphology of the root system, increasing the number of physiologically active lateral roots (Rima et al., 2011).

The reduction in the values of production parameters, observed after the peak of production of certain variable (around $5 \mathrm{~mL} \mathrm{dm}^{-3}$ ), may have been due to the deleterious effects caused by the high dose of the organomineral fertilizer (Figures 1A to 1E). According to Canellas \& Façanha (2004), the mechanisms of action of HSs are difficult to explain, because of the nature and complexity of humic molecules. For Baldoto et al. (2012), HSs may have auxin-like hormone effect; thus, at high doses, they may harm plant development. Therefore, this is probably one of the reasons for the negative effects on plant height, root and shoot dry matter and grain yield in the present study.

Soybean plants subjected to water stress showed lower contents of nitrogen $(\mathrm{N})$, phosphorus $(\mathrm{P})$ and potassium $(\mathrm{K})$ and higher contents of sulfur $(\mathrm{S})$ in the diagnostic leaves (Figures 2A to 2D). In spite of that and except for $\mathrm{K}$, the leaf contents of these nutrients are within the sufficiency range proposed by Malavolta et al. (1997). In addition, there was response to HSs, according to the regression equations, with adjustments to a quadratic model.

The increase of $\mathrm{N}$ contents in the leaves of soybean plants in response to the doses may be associated with the beneficial influence of HSs on the activity of enzymes involved in the metabolism and absorption of this nutrient. Panuccio et al. (2001), studying Pinus plants, concluded that HSs stimulated the absorption of $\mathrm{NH}_{4}^{+}$. The lower contents of $\mathrm{N}$ in plants
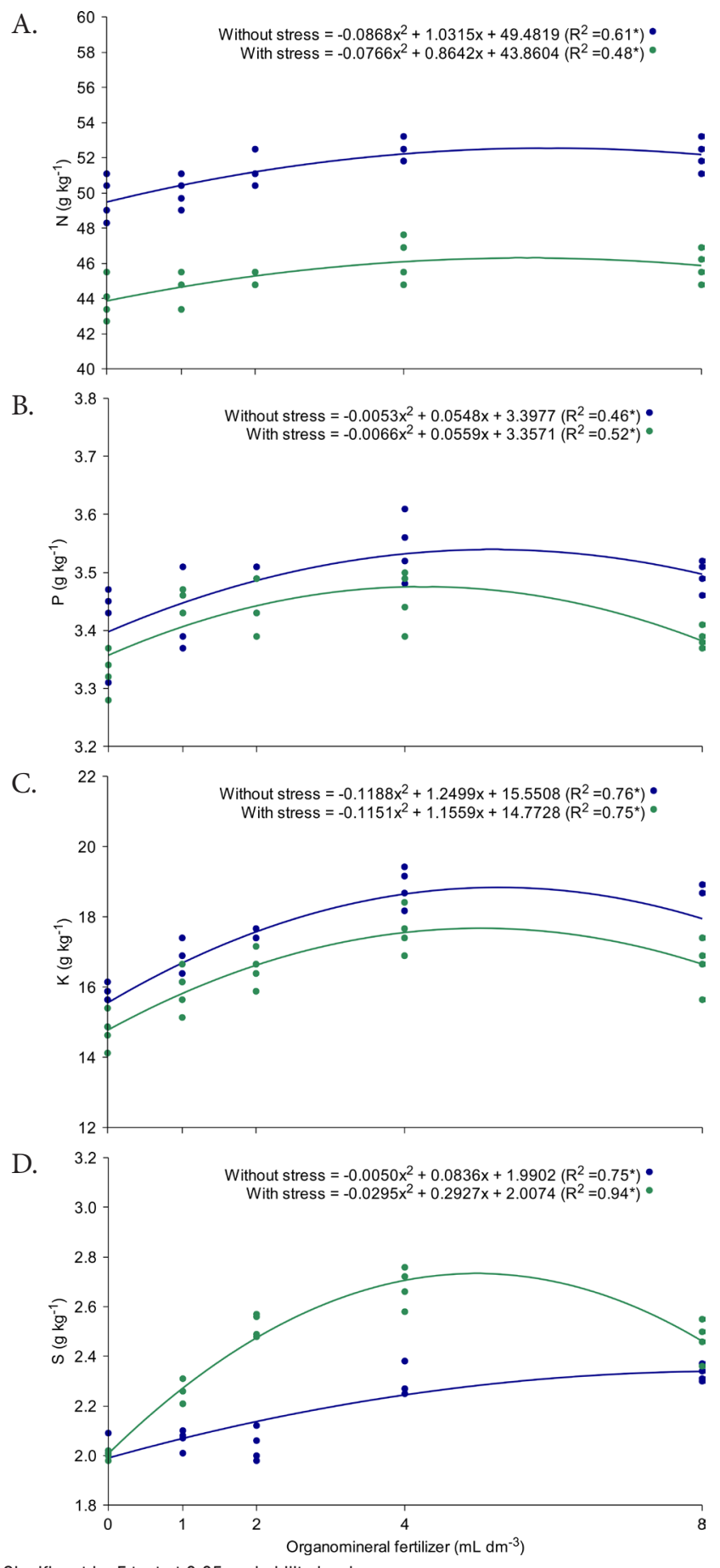

*Significant by $\mathrm{F}$ test at 0.05 probability level

Figure 2. Contents of macronutrients in the leaf tissue of soybean plants as a function of doses of organomineral fertilizer with and without stress: nitrogen - N (A), phosphorus $-\mathrm{P}(\mathrm{B})$, potassium $-\mathrm{K}(\mathrm{C})$ and sulfur $-\mathrm{S}(\mathrm{D})$

subjected to water stress may have occurred due to a lower microbiological activity, caused by the lack of water and, consequently, lower mineralization of the soil organic matter and the organomineral fertilizer. In addition, water stress may have negatively affected the nodulation of soybean plants, reducing the biological fixation of $\mathrm{N}$ and its availability to plants.

The increments in leaf contents of $\mathrm{P}$ may be related to its higher availability in the soil, since HSs can block $\mathrm{P}$ adsorption sites through $\mathrm{Fe}$ and $\mathrm{Al}$ hydroxides, compete with the adsorption sites of the mineral fraction and make the adsorbed 
$\mathrm{P}$ available for assimilation by plants (Guppy et al., 2005). However, according to Matias (2010) and Cessa et al. (2010), high doses of HSs have negative effect on the availability of $\mathrm{P}$, because they favor the formation of organometallic complexes and their adsorption. Andrade et al. (2007) compared the use of humic acids, acetic acid and citric acid, and concluded that the addition of humic acids promoted the best results for corn, which led to greater accumulations of biomass and $\mathrm{P}$ in the plants.

Regarding K, HSs favor the increase in the leaf K contents to a sufficiency level, probably due to the $\mathrm{K}$ present in the organomineral fertilizer, according to Figure 2C. Hartz \& Bottoms (2010), studying tomatoes, did not obtain positive response for leaf $\mathrm{K}$ contents when products containing HSs were applied, and attributed it to the low dose recommended by the manufacturers.

Leaf S contents, different from N, P and K, were higher in soybean plants cultivated under water stress conditions (Figure 2D). The highest $\mathrm{S}$ concentration, in this case, may be associated with the need for synthesis of defense compounds in the plants against the oxidative stress from the secondary metabolism (Gil \& Tuteja, 2010; Chan et al., 2013). In addition, the increment in the concentration of this nutrient may be related to the mineralization of the organic matter, which may contribute to the greater availability of $\mathrm{N}$ and $\mathrm{P}$ in the soil and, consequently, greater absorption and concentration of this element (Stevenson, 1994).

Plants subjected to water stress showed lower contents of micronutrients in the diagnostic leaf; however, all the contents were within the sufficiency range, according to Malavolta et al. (1997) (Figures 3A to 3D). The contents of micronutrients increased, following a quadratic model, as a function of the doses of organomineral fertilizer, in both cultivation environments.

Botero et al. (2010) claim that HSs can form stable complexes with divalent cations such as $\mathrm{Cu}, \mathrm{Mn}$ and $\mathrm{Zn}$, facilitating their transport and availability to plants. As to Fe, besides the aspects mentioned by Botero et al. (2010), the increase in Fe contents in the plant may also have been favored by the reduction of $\mathrm{Fe}^{3+}$ to $\mathrm{Fe}^{2+}$ in medium containing HSs, the latter of which is more available to plants (Adani et al., 1998). Stevenson (1994) reports that HSs with predominance of carboxylic groups and lower molecular weight are more efficient at making micronutrients available to plants, because there can be higher absorption and, consequently, higher leaf contents of these micronutrients, as observed in Figures $3 \mathrm{~A}$ to $3 \mathrm{D}$. However, organomineral fertilizer doses above $5 \mathrm{~mL}$ $\mathrm{dm}^{-3}$ of soil reduced the leaf contents of micronutrients in soybean plants. Zandonadi et al. (2014) claim that this is due to the complexation of these elements by HSs, depending on their concentration and soil $\mathrm{pH}$, making them less soluble and available to plants.

Soybean grain yield was severely affected by the water stress condition and there was a reduction of more than $50 \%$ in grain yield (Figure 4). The best responses for grain yield occurred at the organomineral fertilizer dose of $5 \mathrm{~mL} \mathrm{dm}^{-3}$, without water stress, and $5.4 \mathrm{~mL} \mathrm{dm}^{-3}$, with water stress.

In both conditions of soil moisture, soybean yield increased until the doses of 5 and $6 \mathrm{~mL} \mathrm{dm}^{-3}$ of organomineral fertilizer
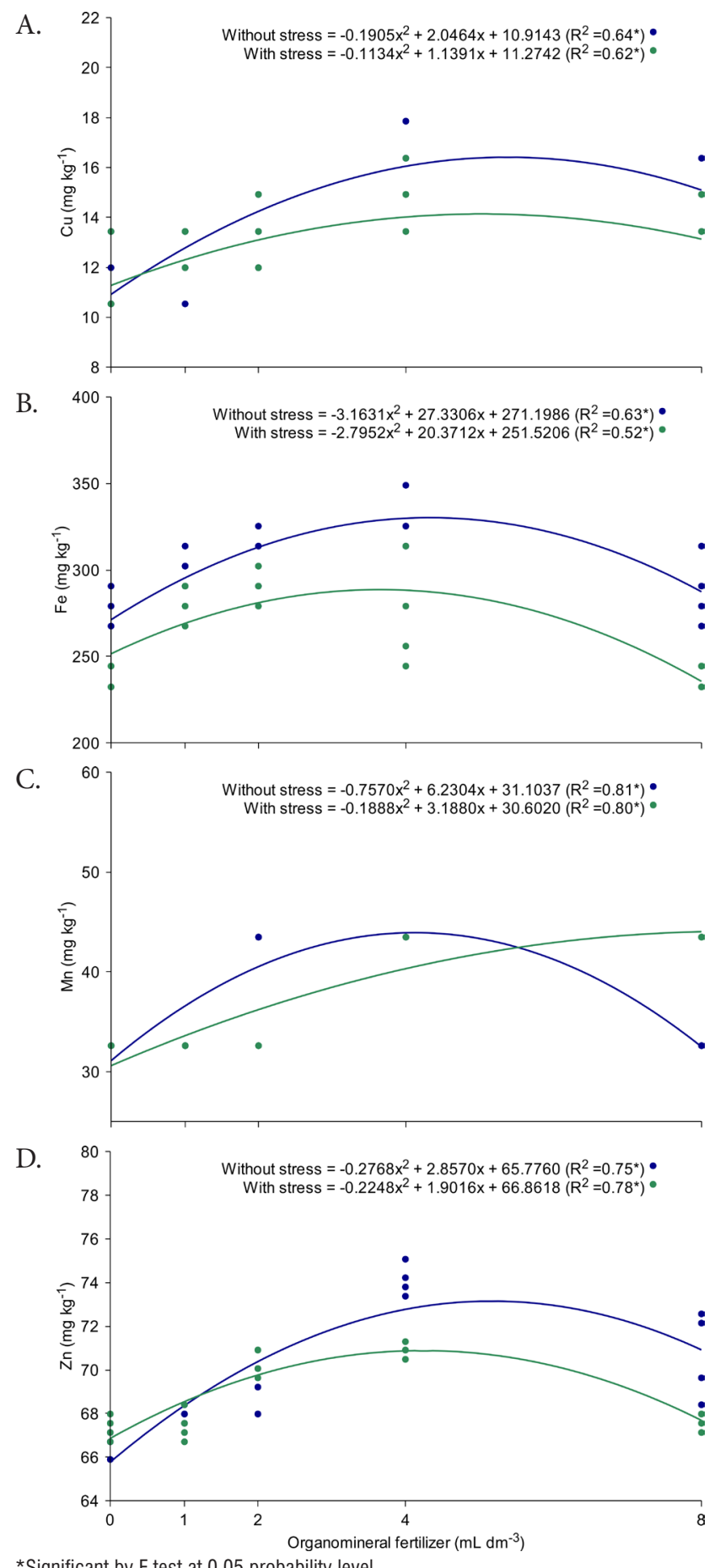

* Significant by $\mathrm{F}$ test at 0.05 probability level

Figure 3. Contents of micronutrients in the leaf tissue of soybean plants as a function of doses of organomineral fertilizer with and without stress: copper - $\mathrm{Cu}(\mathrm{A})$, iron Fe (B), manganese - Mn (C) and zinc - Zn (D)

and, from this point on, it decreased. In general, higher doses negatively affected grain yield, indicating that the use of HSs in high doses may harm plant development. Ayuso et al. (1998) attributed the reduction in barley yield, under high HS concentrations, to the formation of organometallic complexes of high molar mass, which resulted in the decrease of the concentration of micronutrients in nutrient solution, thus compromising their absorption by the plant.

Among the few studies on soybean in Brazil, Benites et al. (2006) reported mean increase of $17 \%$ in grain yield for foliar application of organomineral fertilizer and solutions of 


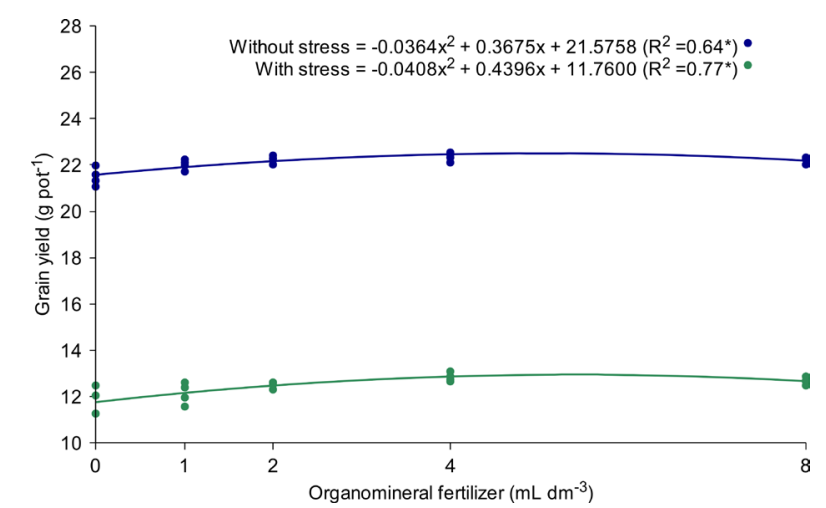

*Significant by $F$ test at 0.05 probability level

Figure 4. Grain yield of soybean plants as a function of doses of organomineral fertilizer with and without stress

humic acid. On the other hand, Hartz \& Bottoms (2010) tested five commercial formulations of products based on HSs and concluded that the products applied via soil did not increase tomato yield, which was attributed to the low doses used by the farmers.

Various authors (Benites et al., 2006; Andrade et al., 2007; García et al., 2012; Canellas \& Olivares, 2014; Zandonadi et al., 2014) mention that HSs improve the agronomic performance of many crops under conditions of nutritional or climatic stress; however, in the present study, the organomineral fertilizer enriched with HSs was not efficient at effectively mitigating the adverse effects of environmental stress, probably due to the severity of the stress to which soybean plants were subjected.

\section{Conclusions}

1. The organomineral fertilizer improves soybean growth, development, mineral nutrition and grain yield.

2. Humic substances favor the absorption of micronutrients under water stress condition until the dose of $189 \mathrm{mg}$ of C $\mathrm{dm}^{-3}$ of soil.

3. The organomineral fertilizer was not able to mitigate the water stress to which soybean plants were subjected.

\section{Literature Cited}

Adani, F.; Genevini, P.; Zaccheo, P.; Zocchi, G. The effect of commercial humic acid in tomato plant growth and mineral nutrition. Journal Plant Nutrition, v.21, p.561-575, 1998. http://dx.doi. org/10.1080/01904169809365424

Andrade, F. V.; Mendonça, E. S.; Silva, I. R.; Mateus, R. F. Dry matter production and phosphorus accumulation by maize plants in response to the addition of organic acids in Oxisols. Communications in Soil and Science and Plant Analysis, v.38, p.2733-2745, 2007. http://dx.doi.org/10.1080/00103620701662976

Ayuso, M.; Hernandez, T.; Garcia, C.; Pascual, J. A. Stimulation of barley growth and nutrient absorption by humic substances originating from various organic materials. Biology and Technology, v.57, p.251-257, 1998.

Baldoto, L. E. B.; Baldotto, M. A.; Soares, R. R.; Martinez, H. E. P.; Venegas, V. H. A. Adventitious rooting in cuttings of croton and hibiscus in response to indolbutyric acid and humic acid. Ceres, v.59, p.476-483, 2012. http://dx.doi.org/10.1590/S0034737X2012000400007
Benites, V. M.; Polidoro, J. C.; Menezes, C. C.; Beta, M. Aplicação foliar de fertilizante organo-mineral e soluções de ácido húmico em soja sob plantio direto. Rio de Janeiro: Embrapa Solos, 2006. 6p. Circular Técnica, 35

Botero, W. G.; Oliveira, L. C.; Rocha, J. C.; Rosa, A. H.; Dos Santos, A. Peat humic substances enriched with nutrients for agricultural applications: competition between nutrients and non-essential metals preset in tropical soils. Journal of Hazardous Materials, v.177, p.307-311, 2010. http://dx.doi.org/10.1016/j. jhazmat.2009.12.033

Canellas, L. P.; Façanha, A. R. Relationship between nature of soil humified fractions and their bioactivity. Pesquisa Agropecuária Brasileira, v.39, p.233-240, 2004. http://dx.doi.org/10.1590/S0100204X2004000300005

Canellas, L. P.; Olivares, F. Physiological responses to humic substances as plant growth promoter. Chemical and Biological Technologies in Agriculture, v.1, p.1-11, 2014. http://dx.doi. org/10.1186/2196-5641-1-3

Cessa, R. M.; Vitorino, A. C. T.; Celi, L.; Novelino, J. O.; Varveris, E. Adsorção de fósforo em frações argila na presença de ácido fúlvico. Revista Brasileira de Ciência do Solo, v.34, p.1525-1542, 2010. http://dx.doi.org/10.1590/S0100-06832010000500006

Chan, K. X.; Wirz, M.; Plua, S. Y.; Satavillo, G. M.; Pogson, B. J. Balacing metabolites in drought: the sulfur assimilation conundrum. Trends in Plant Science, v.18, p.1360-1385, 2013. http://dx.doi.org/10.1016/j.tplants.2012.07.005

Duplessis, G. L.; Mackenzie, A. F. Effects of leonardite aplications on phosphorus availability and corn growth. Canadian Journal Scientific, v.57, p.749-751, 1983.

EMBRAPA - Empresa Brasileira de Pesquisa Agropecuária. Manual de métodos de análise de solo. 2.ed. Rio de Janeiro: SNLCS, 1997. 212p.

EMBRAPA - Empresa Brasileira de Pesquisa Agropecuária. Sistema brasileiro de classificação de solos. 2.ed. Rio de Janeiro: CNPS, 2006. 306p.

Eyheraguibel, B.; Silvestre, J.; Morard, P. Effects of humic substances derived from organic waste enhancement on the growth and mineral nutrition of maize. Biorescource Technology, v.99, p.43064212, 2008. http://dx.doi.org/10.1016/j.biortech.2007.08.082

García, A. C.; Santos, L. A.; Izquierdo, F. G.; Sperandio. M. V. L.; Castro, R. N.; Berbara, R. L. L. Vermicompost humic acids as an ecological pathway to protect rice plant against oxidative stress. Ecological Engineering, v.47, p.203-208, 2012. http://dx.doi. org/10.1016/j.ecoleng.2012.06.011

Gil, S. S.; Tuteja, N. Reactive oxygen species and antioxidant machinery in abiotc stress tolerance in crop plants. Plant Physiology and Biochemistry, v.48, p.909-930, 2010. http://dx.doi. org/10.1016/j.plaphy.2010.08.016

Guppy, C. N.; Menzies, N. M.; Moody, P. W.; Blamey, F. P. C. Competitive sorption reactions between phosphorus and organic matter in soil: A review. Australian Journal of Soil Research, v.43, p.189-202, 2005. http://dx.doi.org/10.1071/SR04049

Hartz, T.; Bottoms, T. Humic substances generally ineffective in improving vegetable crop nutrient uptake or productivity. Hort Science, v.45, p.906-910, 2010.

Malavolta, E.; Vitti, G. C.; Oliveira, S. A. Avaliação do estado nutricional das plantas: Princípios e aplicações. 2.ed. Piracicaba: POTAFOS, 1997. 319p. 
Matias, G. C. S. Eficiência agronômica de fertilizantes fosfatados em solo com diferentes capacidades de adsorção de fósforo e teores de matéria orgânica. Piracicaba: ESALQ, 2010. 134p. Tese Doutorado

Nikbakht, A. Kafi, M.; Babalar, M.; Xia, Y. P.; Luo, A.; Etemadi, N. Effect of humic acid on plant growth, nutrient uptake and postharvest life of gerbera. Journal of Plant Nutrition, v.31, p.2155-2167, 2008. http://dx.doi.org/10.1080/01904160802462819

Panuccio, M. R.; Muscolo, A.; Nardi, S. Effects of humic substances on nitrogen uptake and assimilation in two species of pinus. Journal of Plant Nutrition, v.24, p.623-704, 2001. http://dx.doi. org/10.1081/PLN-100103663

Rima, J. A.; Martim, S. A.; Dobbss, L. B.; Evaristo, J. A.; Retamal, C. A.; Façanha, A. R.; Canellas, L. P. Adição de ácido cítrico potencializa a ação de ácidos húmicos e altera o perfil protéico da membrana plasmática em raízes de milho. Ciência Rural, v.41, p.614-620, 2011. http://dx.doi.org/10.1590/S0103-84782011000400011

Sousa, D. M. G.; Lobato, E. Cerrado: Correção do solo e adubação. 2.ed. Brasília: Embrapa Informação Tecnológica, 2004. 416p.
Stevenson, F. J. Humus chemistry: Genesis, composition, reactions. 2.ed. New York: John Wiley and Sons, 1994. 496p.

Swift, R. S. Organic matter characterization. In: Sparks, D. L.; Page, A. L.; Helmke, P. A.; Loeppert, R. H.; Soltanpour, P. N.; Tabatabai, M. A.; Johnston, C. T.; Sumner, M. E. (ed.) Methods of soil analysis: Part 3: Chemical methods. Madison: SSSA, 1996. p.1011-1020.

Tedesco, M. J.; Gianello, C.; Bissani, C. A. Análise de solo, plantas e outros materiais. Porto Alegre: UFRGS, 1995. 174p.

Vasconcelos, A. C. F. de; Zhang, X.; Ervin, E. H.; Kiehl, J. C. Enzimatic antioxidant responses bioestimulats maize and soybean subjected to drought. Scientia Agrícola, v.66, p.395-402, 2009. http://dx.doi.org/10.1590/S0103-90162009000300015

Zandonadi, D. B.; Santos, M. P.; Medici, L. O.; Silva, J. Ação da matéria orgânica e suas frações sobre a fisiologia de hortaliças. Horticultura Brasileira, v.32, p.14-20, 2014. http://dx.doi. org/10.1590/S0102-05362014000100003

Zandonadi, L. P.; Busato, J. G. Vermicompst humic substances: technology for converting pollution into plant growth regulators. International Journal of Environmental Science and Engineering Research, v.3, p.73-84, 2012. 